\title{
Lexical Borrowing Bearing Witness to the Notions of Gender and Inflection Class: A Case Study on Two Contact Induced Systems of Greek
}

\author{
Dimitra Melissaropoulou \\ Department of Philology, University of Patras, Patras, Greece \\ Email: dmelissa@upatras.gr
}

Received June $6^{\text {th }}, 2013$; revised July $9^{\text {th }}, 2013$; accepted July $18^{\text {th }}, 2013$

\begin{abstract}
Copyright $(92013$ Dimitra Melissaropoulou. This is an open access article distributed under the Creative Commons Attribution License, which permits unrestricted use, distribution, and reproduction in any medium, provided the original work is properly cited.
\end{abstract}

\begin{abstract}
This paper provides a comparative analysis of nominal loanword integration in two different contact induced systems of Greek (i.e. Grico and Capapadocian) in order to offer further insights into two major grammatical categories, those of inflection class and gender (from a morpho-semantic viewpoint, i.e. gender assignment). By providing an analysis of the general mechanisms (e.g. natural gender, formal correspondences, semantic equivalences, analogy) which account for the integration of loanwords in the examined systems it is shown that notwithstanding the divergence, grammatical gender splits into its two major primitives, the semantic one relating to sex and animacy and the structural one, i.e. as an inflectional classifier - in correlation with the notion of inflection class - in the organization of nominal classification types, offering further support to the claim that gender is not a purely morphological or a purely semantic category, but a combination of the two. Each one of the two different facets of grammatical gender along with the notion of inflection class conjoins the need of the systems to provide some type of classification in nouns. However, the realization of those two facets, of one, or none of them, is subject to parametric variation depending, especially in contact induced varieties, on the interplay between the grammatical properties of all the involved systems (i.e. system compatibility, simplification phenomena). The present study is a contribution to the overall language contact studies as well as to the studies on grammatical gender and inflection class and their role in the organization of grammar, emphasizing the role of loanwords in revealing aspects of this organization.
\end{abstract}

Keywords: Nominal Loanwords; Grammatical Gender; Inflection Class; Language Contact; Grico; Cappadocian; Greek

\section{Introduction}

Lexical borrowing, and more specifically loanword integration, is a favorite topic in linguistic studies both for theoretical and applied reasons (cf. Haspelmath, 2008 for relevant discussion), among which its invaluable contribution to the understanding of the organization of grammar. In situations of language contact, the first loan elements that are inarguably transferred from one language into the other are words (cf. Weinreich $^{1}, 1968$; Thomason \& Kaufman, 1988; Haspelmath \& Tadmor, 2009). Thus, loanwords, as the most commonly attested language contact phenomenon, have attracted the attention of linguistic research in many different perspectives, touching upon different linguistics subfields (e.g. phonetics, phonology, morphology, semantics, sociolinguistics, and historical linguistics). Some of the major questions that are tackled in the study of lexical borrowing involve: a) the nature of loanwords, b) the borrowability of different spheres of the vocabulary or of different grammatical categories, c) their adaptation strategies, d)

\footnotetext{
${ }^{1}$ When two divergent systems are spoken within the same territory, lexical units are the first items to be transferred from the one system to the other, the situation that Weinreich (1968: p. 1) refers to as interference.
}

their place in the Lexicon etc.

The aim of this paper is to provide a comparative analysis of nominal loanword integration in two different contact induced systems of Greek in order to offer further insights into two major grammatical categories, those of inflection class and gender $^{2}$ from a morpho-semantic viewpoint (i.e. gender assignment) rather than a syntactic one (i.e. gender agreement).

Furthermore, although integration of loanwords in the standard variety has been treated and led to relevant publications (cf. Anastasiadi-Symeonidi, 1994; Christophidou, 2003 for Standard Modern Greek), this is the first attempt to make a comparative analysis of the integration of loanwords in contact induced dialects which are in contact with both typologically and genetically divergent linguistic systems.

In this vein, our data involve, on the one hand, Cappadocian in contact with the agglutinative Altaic Turkish, while on the other hand, Grico, in contact with the semi-fusional analytic Indo-

${ }^{2}$ Counterarguments on the status of gender as a central grammatical category lie in the fact that it is not present in all attested languages and that, even when present, its status may vary in strength or clarity (for relevant discussion cf. Bichakjian, 1999; Trudgill, 1999; McWhorter, 2001). 
European Italian. The data under investigation are extracted from the available written sources (among others Tommasi, 1996; Stomeo, 1996; Karanastasis, 1997; Rohlfs, 1977; Filieri, 2001; Dawkins, 1916; Mavrochalyvidis, 1990; Janse, forthcoming; Sasse, 1992 etc.) as well as from the oral corpora of the Laboratory of Modern Greek dialects at the University of Patras.

Our presentation is organized as follows: Section 2 summarizes basic premises and assumptions on the notions of gender, inflection class, loanwords, and loanword integration mechanisms. In Section 3, a sketchy description of the sociolinguistic background is offered and all the relevant data are presented accompanied by generalizations on the attested phenomena. In Section 4, discussion, specific claims and proposals are put forward in order to account for the commonalities and the particularities of the role and the realization of gender and inflection class in the two divergent language contact situations, showing that in any case gender is a metalinguistic category with two different facets - one semantic, which is thought to have a universal basis - and one morphological - the realization of which is subject to parametric variation depending, especially in contact induced varieties, on the interplay between the grammatical properties of the involved systems. The paper ends with a brief summary of the main points of this contribution.

\section{Premises}

The notion of inflection class has been studied in depth and several approaches (among others Carstairs, 1987; Dressler, 1987; Carstairs-Mc Carthy, 1994; Ralli, 2000, 2006; Corbett, $2005,2007,2008$ ) have been proposed in order to account for it as a classifier of nouns into different groups based on varied criteria. On the other hand, notwithstanding the respectable relevant literature (among others Corbett, 1991, 2005; Corbett \& Fraser, 2000; Dahl, 2000a,b,c), grammatical gender is still to some extent obscure, especially if one takes into account that, on the one hand, it complicates morphological production, while on the other hand, there are languages that do perfectly without $\mathrm{it}^{3}$.

For reasons of clarity we should mention from the very beginning that gender is conceived of as a bipartite notion subdivided into natural and grammatical gender ${ }^{4}$. Natural gender is closely related to animacy, i.e. refers to the sex of human beings and animals (gender distinctions often cut through on different places of the animal kingdom continuum (cf. Dahl, 2000a: pp. 99-100), since it is often the case that some higher animals are treated as persons, while some lower ones as inanimate entities. Thus, the cutoff point varies cross-linguistically ${ }^{5}$.

On the other hand, grammatical gender is often argued to have no semantic correlates. However, as argued by Aksenow (1984) all gendered languages have both a semantic and a non-semantic pole. As is well known there are languages that realize only natural gender (e.g. English, Turkish, Hungarian) but not

\footnotetext{
${ }^{3}$ No matter the lack of general consensus both within and across different linguistic approaches on what the major grammatical categories are, gender is usually listed among them (see among others Bybee, 1985, or earlier Bloomfield, 1933 and Lyons, 1977).

${ }^{4}$ The distinction and the correspondences between natural and grammatical gender were firstly discussed by early Greek scholars such as Aristotle, Stoics and Dionysius Thrax.

${ }_{5}^{5}$ In many Indo-European languages, humans and some - admittedly varyinghigher animals bear masculine or feminine gender on the basis of their sex, while in-animates and lower animals on the basis of formal or other criteria.
}

grammatical one. Thus, grammatical gender is not cross-linguistically obligatory and from this view-point it is often considered as a "less central category" (see Trudgill, 1999: p. 134) ${ }^{6}$.

In this perspective, it is often alluded an arbitrary in terms of semantic content ${ }^{7}$ (see among others Hickey, 1999) or even luxurious and admittedly non universal character, in the sense that compared to other categories it serves no specific function neither in grammar nor in human communication, plus languages can do perfectly without it. As such, it is argued to be extremely vulnerable and easily subject to change when the language contact factor is at play ${ }^{8}$. Interestingly, no pidgin language is reported to have grammatical gender distinctions, while its reintroduction remains extremely rare in cases of creolization ${ }^{9}$. Nevertheless, the role of gender as a system of formal classification based on morphological and phonological parameters or those as well has been recognized ${ }^{10}$, although lack of regularity has been attributed in this case as well.

One important aspect of the realization of gender in loanword elements, as part of their integration process, concerns the interaction between grammatical gender and the notion of inflection class. In languages with rich morphology, the notions of gender and inflection are acknowledged to be strongly related (among others Corbett, 1991; Aronoff, 1994; Dressler \& Thorton, 1996; Ralli, 2000, 2002 etc.). However, grammatical gender cannot be thought of as being identical with a specific inflection class type though there is a frequent correlation between the two categories. It is often the case that from the phonological shape of a word and its gender the inflection class can usually be deduced.

There have been proposed totally opposite theses - usually on the basis of a specific linguistic system - on which of the two notions dominates the other ${ }^{11}$. Aronoff (1994: p. 74) claimed that the gender to class dominance is the "normal" direction while the opposite the class to gender dominance the 'inverted' one. However, a universal principle cannot be established and this relationship admittedly varies cross-linguistically.

With respect to Greek, Ralli $(2000,2002)$ following a generative tradition, although she does not underestimate the role of semantics for the assignment of a specific grammatical gender value on the basis of animacy, argues that the role of morphology (related to the processes of inflection, derivation, and compounding) is more important in grammatical gender assign-

\footnotetext{
${ }^{6}$ Admittedly, the realization of natural gender is much less obscure or puzzling than that of grammatical gender in the sense that the former distinguish between males and females, which is a basic biological and social distinction between humans.

${ }^{7}$ Following Hickey (1999: pp. 3-4), grammatical gender can obtain a semantic function in those cases where the only formal distinction between words of different meaning is to be found in the article they take. However, the reverse situation seems to occur as well, since different articles can also be used with the same form without a semantic distinction being involved.

${ }^{8}$ Grammatical gender constitutes a vulnerable domain for variation and change in language contact situations (see among others Cornips, 2008; Bakker, 1997).

${ }^{9}$ For the purposes of this paper no consideration of pidgins and creoles (cf. Mufwene, 2001), mixed languages (cf. Bakker \& Mous, 1994), or contact languages per se (cf. Wurm et al., 1996) is made since our focus is on contact induced varieties.

${ }^{10}$ Braunmüller (2000: 33) argues that "only grammatical rules operate in languages with a three-gender system [where the] use of gender is restricted to the morphological and syntactic level".

${ }^{11}$ Unsurprisingly, totally different accounts for the direction of dominance (gender $\rightarrow$ inflection class or viceversa) have been offered for the same language (e.g. Russian cf. Corbett, 1991; Aronoff, 1994) as well.
} 
ment ${ }^{12}$. Although both gender and inflection class provide a type of classification for nouns, they do not coincide, not in all different cases at least.

Christophidou (2003: p. 114) on the other hand, within a natural morphology framework and focusing on the productivity of the (productive) inflection classes, argues that in Greek there is a mono-directional relationship between gender and inflection class, in the sense that inflection class could be described on the basis of gender ${ }^{13}$.

As regards lexical borrowing, following Johanson (1992), it can be defined as the process of copying a form from one language system into another, with or without all the meanings it expresses in the source language. (Lexical) borrowings often referred to as loanwords, transfers or copies are subject to different classifications depending on various criteria e.g. the degree of their integration to the recipient system, their frequency of use, the agents of transfer etc. (see Bloomfield, 1993; Van Coetsem, 1988). Although the classification of loanwords varies depending on the viewpoint from which they are studied, the classification provided by Haugen $(1950,1953)$ remains seminal and is adopted for the purposes of this paper as well. He proposed a tripartite categorization of borrowed elements into: a) loanwords, which copy both the form and the meaning b) loanblends, consisting of combinations of borrowed and native forms and c) loanshifts referring only to the copy of the meaning. The examined elements are thought to be part of the first class, i.e. loanwords, in the sense that - apart from fitting the definition - they are fully adapted to the recipient system and participate in other phonological and grammatical processes.

As widely acknowledged in the relevant literature, in several circumstances, lexical borrowings, namely loanwords have to be adapted to the morphological system of the recipient languages (Sankoff, 2001). More specifically, when nouns are transferred into gendered languages or into languages with noun-class systems, the former should obligatorily come to certain re-arrangements so as to fit the new categories. Loanword grammatical gender and/or inflection class assignment is said to be subject to a variety of criteria, phonological, morphological, and semantic of combinatorial nature. Although they may be subject to parametric variation depending on the involved systems, the main mechanisms governing loanword integration are considered to be the following (cf. Ibrahim, 1973; Poplack, Pousada, \& Sankoff, 1982; Corbett, 1991; Thornton, 2001; Winford, 2010):

a) The natural gender (sex) of the referent.

b) The formal (phonological-structural) shape of the word.

c) Analogy to the recipient language suffix.

d) Analogy to the recipient language semantic equivalent ${ }^{14}$ (semantic analogy).

However, apart from factors reflecting the dynamics-characteristics of the recipient system, Anastasiadi-Symeonidi (1994: pp. 189-190), proposed that when a loan element comes from a gendered donor language, its value may influence the value it will be assigned in the recipient language, while Stolz

\footnotetext{
${ }^{12}$ Ralli $(2002,2003)$ considers gender to be a lexical feature whose information has to be listed in the Lexicon, since in several cases neither the semantics nor the morphology can account for the assignment of a specific grammatical gender value. Thus, gender assignment in SMG is considered only partially predictable.

${ }^{13}$ In SMG gender is argued to have priority over inflection class, since all loans or neologisms are assigned grammatical gender whether inflected or not.

${ }^{14}$ This principle is also referred to as "the closest lexical equivalent" (Carstensen, 1980: p. 15ff.).
}

(2009) advocates that the source language as well may employ special strategies such as the preference for a default gender (see also Kilarski, 2003) or for a special gender-noun class.

Lastly, we should notice that loanwords are a very important empirical test bed in order to confirm whether grammatical gender assignment is part of the organization of grammar, i.e. is part of the native speaker's competence, since when new nouns enter a system they must be given a gender and become members of a specific group of nouns. What is really important is to see how assignment rules operate on elements that often are quite unlike the native vocabulary. Let us now examine the dialectal data after a sketchy description of the dialects sociolinguistic background.

\section{Data}

\section{Grico}

\section{Sociolinguistic Background}

The dialectal variety of Grico is spoken in Southern Italy, in the area of Puglia, Salento, widely known as Grecia Salentina (cf. Karanastasis, 1984), The dialectal enclave of Grico is situated at the heart of Salentino peninsula and consists of nine communities: Calimera, Castrignano dei Greci, Corigliano d' Otranto, Zollino, Sternatia, Martano, Martignano, Melpignano, and Soleto (cf. Karanastasis, 1984: p. $1 \alpha^{\prime}$; Profili, 1985). The sociolinguistic status of this Greek-speaking enclave varied during centuries. Till 80's Grico was in danger of extinction. The last decades, it experiences some revitalization efforts (cf. Caratzas, 1958; Profili, 1999a,b), having as a starting point its official recognition as a minority language (1999).

Being spoken for great many centuries in an Italian area (see Minas, 1994, 2004; Manolessou, 2005 and references therein for the different opinions with respect to Grico origin, i.e. Ancient Greek vs. Byzantine Greek ${ }^{15}$ ), Grico was in long term contact with Italian, not only in its standard form (the language of school and media), but in the local Romance varieties as well, (dialetti salentini), used in every day speech (street conversations, local commerce), a situation that inevitably limited the sphere of its usage to family situations (cf. Profili, 1985; Katsoyannou, 1996, 1999). Following Profili (1999a), speakers of Grico do not advocate a Greek identity. They are Italian citizens and their national identity is Italian. The dialectal varieties constitute for them a link that brings them closer to their Greek neighbors from a viewpoint of mentality and culture, but no genetic bond is implied in anyway.

\section{Grammatical Gender Assignment in Grico Loanwords}

As already mentioned in the previous sections, Grico variety is a three-gendered system. It distinguishes between masculine, feminine, and neuter nouns. More specifically Grico distinguishes between masc(uline) nouns in $-a,-i$, and $-o$, fem(inine) nouns in $-a$, and neu(ter) nouns in $-o,-i$, and $-a$, as shown in the examples under (1), (2), and (3) respectively.

(1) Masculine nouns in $-a,-i$, and $-o$

$$
\text { -a: mina "month" }
$$

${ }^{15}$ Traditional research vacillates between the Byzantine and the Ancient Greek origin. However, the study of the sociolinguistic background of the area in modern sociolinguistic terms, contributed significantly to ease off the conflict, focusing on the coexistence of the two language forms (Grico and Italian) for great many centuries in the area as well as their mutual influence (cf. Fanciullo, 2001; Manolessou, 2005 for a more detailed discussion on the nature of this question). 


$$
\begin{array}{ll}
\text {-i: } \text { t } \text { furi } & \text { "master" } \\
\text {-o: milo } & \text { "mill" }
\end{array}
$$

Grico masculine inflectional markers are reminiscent of but not identical with the SMG inflectional affixes (-as e.g. minas "month", -is e.g. ciris "master", and -os e.g. milos 'mill' respectively). This is mainly due to final $-s$ dropping resulting from the preference of Italiot systems for open (CV) syllables.

(2) Feminine nouns in $-a$

-a: jineka "woman"

Feminine nouns seem to be confined basically to one group of nouns those in $-a$, as opposed to SMG and other dialectal varieties where two classes of feminines are distinguished, those in -a (e.g. jineka "woman" and those in $-i$ (e.g. limni "lake"). In Grico variety the vast majority of the former feminine nouns in $-i$ are transferred to the $-a$ group $^{16}$ without the reverse tendency being seriously at play ${ }^{17}$.

(3) Neuter nouns in $-o,-i$, and $-a$

$\begin{array}{ll}\text {-o: fsilo } & \text { "wood" } \\ \text {-i: gala } & \text { "milk" } \\ \text {-a: krovatti } & \text { "bed" }\end{array}$

Adaptation of nominal loan elements seems to show a preference to specific gender-inflection class values. More specifically:

a. nominal loan elements ending in $-a$ (from loan feminine forms in $-a$ ) are generally assigned a feminine grammatical gender value due to their correspondence with the productive feminine $-a$ declension in the Grico system ${ }^{18}$. E.g.:

\begin{tabular}{|c|c|c|c|}
\hline $\begin{array}{l}19 \\
\text { "eagula.FEM }\end{array}$ & $<$ & $\begin{array}{l}\text { acula.FEM } \\
\text { "eagle" }\end{array}$ & Salentino \\
\hline $\begin{array}{l}\text { avina.FEM } \\
\text { "vein" }\end{array}$ & $<$ & $\begin{array}{l}\text { vena.FEM } \\
\text { "vein" }\end{array}$ & Italian/Salentino \\
\hline $\begin{array}{l}\text { tfista. FEM } \\
\text { "basket" }\end{array}$ & $<$ & $\begin{array}{l}\text { cista.FEM } \\
\text { "basket" }\end{array}$ & Salentino \\
\hline $\begin{array}{l}\text { fudd ha.FEM } \\
\text { "hurry" }\end{array}$ & $<$ & 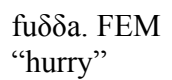 & Salentino \\
\hline
\end{tabular}

(4)

a. Nominal loan elements ending in $-i$ (mainly from loan masculine forms in $-e$ and few from $-i)$, for the account of which other mechanisms may also be involved (e.g. suffix addition, pilaci. $\mathrm{NEU}<$ pila.FEM+aci "must tank" etc.), are generally assigned the neuter grammatical gender value and become members of the $-i$ subgroup of nouns. E.g.:

(5)

$\begin{array}{llll}\begin{array}{l}\text { kapetali.NEU } \\ \text { "pillow" }\end{array} & < & \begin{array}{l}\text { capitale.MASC } \\ \text { "pillow" }\end{array} & \text { Salentino } \\ \text { paisi.NEU } & < & \begin{array}{l}\text { paise.MASC } \\ \text { "country" }\end{array} & \text { Salentino } \\ \text { pitfiuni.NEU } & < & \begin{array}{l}\text { peountry" } \\ \text { "docciune.MASC }\end{array} & \text { Salentino } \\ \begin{array}{l}\text { sapali.NEU } \\ \text { "hedge" }\end{array} & <\begin{array}{l}\text { sapale.MASC } \\ \text { "hedge" }\end{array} & \text { Salentino } \\ \end{array}$

${ }^{16}$ Indications of this change in the inflection class membership of $-i$ nouns are attested in Medieval Greek documents of Italiot and Sicilian Greek, as described by Minas (1994: pp. 88-89), where formerly $-i$ feminine nouns are inflected as ending in $-a$. For example, tin ox $\theta a$ instead of tin ox $\theta i$ "the shore.Acc", tin limna instead of tin limni "the lake.Acc".

${ }_{17}^{17}$ Only the noun tripi instead of tripa "hole" is found in use in Salento. In Calabria the corresponding form is tripa.

${ }^{18}$ As already mentioned by Newton (1963: p. 22), the retention of feminines in $-a$ in both Italian and Grico systems facilitates their transference.

${ }^{19} \mathrm{As}$ regards the convention for transliteration employed throughout the paper, dialectal data are transliterated in broad phonetic transcription, while the corresponding forms in the source systems are exemplified as they ap-

\begin{tabular}{|c|c|c|c|}
\hline $\begin{array}{l}\text { fidd }{ }^{\mathrm{h}} \text { itti.NEU } \\
\text { "fern", }\end{array}$ & $<$ & 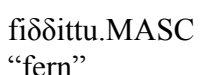 & Salentino \\
\hline $\begin{array}{l}\text { torloci.NEU } \\
\text { "watch" }\end{array}$ & $<$ & $\begin{array}{l}\text { tarloci.MASC } \\
\text { "watch" }\end{array}$ & Salentino \\
\hline
\end{tabular}
pear usually in the sources, using the Latin alphabet. b. Nominal loan elements ending in -o (from loan masculine forms in $-u$ or $-o$ ) are generally assigned the masculine grammatical gender value. E.g.:

\begin{tabular}{|c|c|c|c|}
\hline $\begin{array}{l}\text { fjuro.MASC } \\
\text { "flower" }\end{array}$ & $<$ & $\begin{array}{l}\text { fiuru.MASC } \\
\text { "flower" }\end{array}$ & Salentino \\
\hline $\begin{array}{l}\text { "flower" } \\
\text { fundo.MASC } \\
\text { "fond" }\end{array}$ & $<$ & $\begin{array}{l}\text { fundu.MASC Salenting } \\
\text { "fond" }\end{array}$ & \\
\hline guito.MASC & $<$ & $\begin{array}{l}\text { uitu.MASC } \\
\& \text { gomito.MASC }\end{array}$ & $\begin{array}{l}\text { Salentino } \\
\text { Italian }\end{array}$ \\
\hline $\begin{array}{l}\text { lbow" } \\
\text { lalano.MASC } \\
\text { easant" }\end{array}$ & $<$ & $\begin{array}{l}\text { "elbow" } \\
\text { calanu.MASC Salentin } \\
\text { "peasant" }\end{array}$ & \\
\hline
\end{tabular}

(6)

What can be seen is that from the total of different seven inflectional classes of Grico, nominal loans are adjusted entering three specific inflection classes, one masculine, one feminine, and one neuter. Moreover, this preference is not accidental at all. Masculine nouns in $-o$ and feminine nouns in $-a$ correspond to two of the most productive inflection classes both for Standard Italian and Salentino inflectional systems. Relative examples can be seen under (7) below:

\begin{tabular}{|c|c|c|c|c|}
\hline & \multicolumn{2}{|c|}{ Standard Italian } & \multicolumn{2}{|c|}{ Romance (Salentino) } \\
\hline & Singular & Plural & Singular & Plural \\
\hline \multirow[t]{2}{*}{ Feminine } & $\begin{array}{c}\mathrm{X}-\mathrm{a} \\
\text { donna }\end{array}$ & $\begin{array}{l}\mathrm{X} \text {-e } \\
\text { donne }\end{array}$ & $\begin{array}{l}\mathrm{X}-\mathrm{a} \\
\text { igna }\end{array}$ & $\begin{array}{l}X-e \\
\text { igne }\end{array}$ \\
\hline & \multicolumn{2}{|c|}{ "woman, lady" } & \multicolumn{2}{|c|}{ "fire" } \\
\hline Masculine & $\begin{array}{l}\mathrm{e}^{20} \mathrm{X}-\mathrm{o} \\
\text { marito }\end{array}$ & $\begin{array}{l}\mathrm{X}-\mathrm{i} \\
\text { mariti }\end{array}$ & \multicolumn{2}{|c|}{$\begin{array}{ll}\mathrm{X}-\mathrm{u}(<\mathrm{o})^{21} & \mathrm{X}-\mathrm{i} \\
\text { maritu } & \text { mariti }\end{array}$} \\
\hline
\end{tabular}

(7) Italian productive nominal declensions

(from Melissaropoulou forthcoming)

The choice of neuter in $-i$ inflection class can be accounted for on the basis of the following: on the one hand it is the most productive Grico inflection class, b. it's inflectional marker does not coincide with the markers of the other inflection classes as neuter in $-o$ and $-a$ would do ( $-o$ and $-a$ are found correspondingly in masculine and feminine nouns as well) and c. it is phonologically very close to /e/ the which characterizes another productive declension in Italian (masculine-feminine nouns in - $e$ (plural in -i) e.g. il paese.MASC "country").

Crucially, a contrastive look at the Grico vs. Romance nominal subgroups reveals that there are formal (structural and phonological) correspondences between the two groups of systems that cannot but have contributed to the adaptation of nominal loanwords in the specific inflection classes and their assignment of a specific grammatical gender value. Thus, diamorphemic structural and morphological schemata, in this particular case what we would call dia-classes (cf. Melissaropoulou forthcoming), are proven to influence morphological adaptation and grammatical gender assignment into the Grico system.

According to Anastasiadi-Symeonidi (1994: pp. 189-190), when a loan element comes from a gendered donor language, its value influences the value it will be assigned in the recipient

\footnotetext{
${ }^{20}$ Few feminine nouns in - $o$ can be traced in both Standard Italian and Salentino dialect. E.g. la mano.FEM "hand", la radio.FEM "radio".

${ }^{21}$ In Salentino dialect, the mid vowels and /e/ and /o/ are raised into /i/ and $/ \mathrm{u} /$ respectively when found in final position (cf. Maiden \& Parry, 1997).
} 
language unless other conditions are in operation. In our case study we would add that the formal correspondences, as realized through a specific inflectional marker which bears a specific grammatical gender value, influence the morphological adaptation (both the grammatical gender assignment and the inflection class membership) of loanwords in the recipient system.

Moreover, apart from the formal shape of the word, which seems to play a very crucial role for the vast majority of loanword elements and is highly ranked, there are some other mechanisms involved in grammatical gender assignment of loanwords. These are as follows:

a. The natural gender of the referent. The phonological and structural correspondences can be biased and a different grammatical gender value can be assigned when human nouns or more generally animate nouns ${ }^{22}$ are involved, since in this case nouns have to bear the grammatical gender value that matches their sex (masculine when the referent is male and feminine when female). For example nouns in $-i$ are assigned the neuter grammatical gender value when non-human and the masculine grammatical gender value when human males. You can see the examples under (8) below:

(8)

\begin{tabular}{|c|c|c|c|}
\hline $\begin{array}{l}\text { paisi.NEU } \\
\text { “country” }\end{array}$ & $<$ & $\begin{array}{l}\text { paise.MASC } \\
\text { "country" }\end{array}$ & Salentino \\
\hline but & & & \\
\hline $\begin{array}{l}\text { vutferi.MASC } \\
\text { "butcher" }\end{array}$ & $<$ & $\begin{array}{l}\text { ucceri.MASC } \\
\text { "butcher" }\end{array}$ & Salentino \\
\hline sarturi.MASC & $<$ & sartore.MASC & \\
\hline $\begin{array}{l}\text { "tailor" } \\
\text { spetfiali.MASC } \\
\text { "pharmacist" }\end{array}$ & $<$ & $\begin{array}{l}\text { "tailor" } \\
\text { speciale.ADJ } \\
\text { "particular" }\end{array}$ & Italian/Salentino \\
\hline
\end{tabular}

b. Analogy to the recipient system suffix. The status of suffixes as heads that are marked for a specific gender value and attach to a specific inflectional marker plays also an important role in morphological adaptation of loanword elements, offering further support to the claim that gender is a lexical feature (cf. Spencer, 1999; Ralli, 2003) that actively participates in word-formation processes. You can see the examples below:

(9)

a. vardeddhi.NEU
"pack-saddle"

NOTE: the suffix $-e d d^{h} i$ in the recipient system bears the neuter grammatical gender value.
b. kasciuna.MASC $<$ cascia.FEM Salentino
"big box" "box"

NOTE: the suffix -una in the recipient system bears the masculine grammatical gender value.

$\begin{array}{lll}\text { c. furmikar-ea.FEM }< & \text { furmiculòria.FEM } & \text { Salentino } \\ & \begin{array}{l}\text { furmiculara.FEM } \\ \text { "formication" }\end{array} & \text { Salentino }\end{array}$

NOTE: the suffix -ea in the recipient system bears the feminine grammatical gender value
d. vutfer-ena.FEM $<$ vucceri.MASC Salentino
"female/wife of "butcher"

the butcher"

NOTE: the suffix -ena in the recipient system bears the feminine grammatical gender value, since it forms feminine professional nouns or feminine agent nouns in general from the

\footnotetext{
${ }^{22}$ Some domesticated animals bear the grammatical gender value that
} matches their sex as well. corresponding masculine ones.

However, these formations are not abundant and it is often the case that both simple and derived loan forms are found in the recipient system.

c. Although marginally, analogy to the recipient system semantic equivalent ${ }^{23}$. In few cases the nominal loan does not bear the grammatical gender value that would be expected given the above mentioned mechanisms/parameters (mainly the formal correspondences), but it acquires the grammatical gender value of its semantic equivalent in the recipient system. E.g.:

(10)

fikato.NEU
"liver"

NOTE: the Grico semantic equivalent sikoti is neuter.

faradz/dzo.MASC $<$ farazza.FEM Salentino

"bulb" "bulb"

NOTE: the Grico semantic equivalent volvos is masculine mugnulo.NEU $<$ mugnullo.MASC Salentino "vegetable" "vegetable"

NOTE: the Grico semantic equivalent laxano is neuter spirlingoi.MASC $<$ perlangoi.FEM Salentino "bee-eater" "bee-eater"

NOTE: the Grico semantic equivalent melisofao is masculine In an attempt to generalize and provide a hierarchy of the mechanisms governing grammatical gender assignment in Grico loanwords, we would propose it to be as follows:

Natural gender is ranked in the first-highest position even though formal correspondences govern/determine morphological adaptation for the vast majority of nominal loanwords, since the latter can be biased and a different grammatical gender value can be assigned when human nouns are involved since in this case nouns have to bear the grammatical gender value that matches their sex (masculine when the referent is male and feminine when female). Analogy to the recipient system suffix and semantic analogy are operative in a very small number of loanwords thus are thought of not as prevailing but rather as additional mechanisms.

In cases of structural compatibility among the systems in contact (both are gendered systems although they do not bear the same gender values and display inflection classes that interact with gender) the tendency for the default gender (i.e. the neuter) to be employed for inanimate objects is not borne out. Grammatical gender assignment is thought to be predictable only in those cases where natural gender is involved. In all the other cases the formal (phonological-structural) corresponddences (between the source and the recipient system) prove to be the most powerful mechanism governing morphological adaptation of loanwords. More specifically, from the total of seven different inflectional subgroups in Grico, nominal loans are adjusted entering three specific subgroups, one masculine (in $-o$ ), one feminine (in $-a$ ), and one neuter (in $-i$ ), revealing that formal correspondences between the involved systems contributed to the integration of nominal loanwords in the specific inflection classes and their assignment of a specific grammatical gender value. Let us now turn to Cappadocian.

\section{Cappadocian}

\section{Sociolinguistic Background}

Cappadocian came under the Turkish influence during the late byzantine period, for the first time in the $11^{\text {th }}$ century after the

${ }^{23}$ Some Semantic analogy or concept association in Corbett's (1991) terms. 
Seljuk invasion and subsequently in the $14^{\text {th }}$ century after the conquest of Asia Minor by the Ottoman Turks. It was spoken till 1923 (i.e. till the exchange of populations that followed the treaty of Lausanne in the former Asia Minor (today's central Turkey) in an area that covered 32 communities approximately. The dialect is subdivided into two basic groups, North and South Cappadocian (cf. Dawkins, 1916) and an intermediate one, namely Central Cappadocian (cf. Janse forthcoming) ${ }^{24}$ showing intra-dialectal divergence ${ }^{25}$. Today it is spoken by descendants of Cappadocian refugees (second and third-generation refugees) in several parts of Northern Greece (Kavala, Alexandroupoli, Kilkis, Thessaloniki, Karditsa, Volos, Larisa).

Cappadocian is often used in the literature as a prototypical example of "heavy borrowing" in terms of Thomason \& Kaufman's borrowing scale, referring to "overwhelming long-term cultural pressure" (Thomason \& Kaufman, 1988: p. 50). The length and intensity of cultural and linguistic contact led Dawkins to the following statement about Cappadocian dialect "[...] the body ha[d] remained Greek but the soul ha[d] become Turkish [...]", Dawkins (1916: p. 198). It should be noted that although Cappadocian is originally a Greek variety and its basic morphological structure is fusional, it displays some agglutinative patterns due to language contact with Turkish (cf. Dawkins, 1916; Janse, 2004, 2009, forthcoming).

\section{Grammatical Gender Assignment in Cappadocian Loanwords}

The situation in Cappadocian seems to be quite differentiated compared to that in Grico. In this case, the dominant language, Turkish, is both genetically and typologically divergent, namely it is a non-Indo-European, Altaic, agglutinative, genderless language.

As already acknowledged in the relevant literature (among others Dawkins, 1916; Janse, 2004, forthcoming), Cappadocian holds a prominent position compared to all other Modern Greek dialects and SMG since it is characterized by the following innovations: a. the distinction between animate and inanimate nouns in North and Central Cappadocian, b. the progressive loss of gender distinctions, especially in South Cappadocian (cf. Dawkins, 1916; Janse, 2004, forthcoming and Bakker, 1997 for adaptation of loans), and c. the emergence of a generalized agglutinative declension, innovations that are relevant for the purposes of this paper.

Our presentation of morphological adaptation of loanwords in Cappadocian follows the geographical subdivision into North, Central, and South Cappadocian in order to be able to capture the intra-dialectal divergence, and account for it in terms of mirroring the gradualness of linguistic change towards a specific direction: the establishment of a genderless system.

Crucially, in Cappadocian the original categorization of nouns into different subgroups, i.e. inflection classes, based on their different inflectional endings in combination with their different grammatical gender values, as shown in (11) below, is retained to some extent only in the North Cappadocian zone (and much less to the central Cappadocian zone). The original subgrouping of Cappadocian inflection can be seen from (11) to (13) below:

(11) Masculine nouns in -os, -is, and -as

$$
\text { -os: a } \operatorname{ropos} \text { "man" }
$$

\footnotetext{
${ }^{24}$ For a more detailed categorization of the Cappadocian varieties into zones see the Appendix.

${ }^{25}$ The division of Cappadocian into zones is not clear cut since for example Northeast Cappadocian system is in some aspects similar to that of Axó's which belongs to Central Cappadocian.
}
-is: kleftis
-as: papas
(12) Feminine nouns in $-a,-i$
-a: neka
-i: nif(i)
"thief"
"priest"
-a: konizma "icon"
-o: metapo "forehead"
-i: fti

More specifically, in the admittedly less corrupted North Cappadocian zone (and to Axó, Central Cappadocian zone, to a lesser extent), nouns are assigned a specific grammatical gender value on the basis of the categorical semantic distinction of animacy. Human nouns mainly, few animals as well, (but the distinction is not always consistent), seem to bear a masculine or feminine grammatical gender value, in some environments at least, while non human nouns become neuter, which marks the lack of gender. See examples under (14):

(14)

\begin{tabular}{|c|c|}
\hline \multirow{3}{*}{$\begin{array}{l}\text { a. t } \text { fobanus.MASC }< \\
\text { Delmesó, North Cappadocian } \\
\text { "shepherd" }\end{array}$} & çoban. $\varnothing^{26}$ \\
\hline & Turkish \\
\hline & "shepherd" \\
\hline b. patifahos.MASC $<$ & padišah.Ø \\
\hline Delmesó, North Cappadocian & Turkish \\
\hline "king" & "king" \\
\hline c. herifos. MASC $<$ & herif.Ø \\
\hline Axó, Central Cappadocian & Turkish \\
\hline "man" & "man" \\
\hline d. yərəxos.MASC $<$ & kuyruk.Ø \\
\hline Axós, Central Cappadocian & Turkish \\
\hline "scorpion" & "scorpion" \\
\hline e. balduza.FEM < & baldız.Ø \\
\hline Axós, Central Cappadocian & Turkish \\
\hline "sister-in-law" & "sister-in-law" \\
\hline f. $\mathrm{t}$ fift]is.MASC $\quad<$ & çiftçi.Ø \\
\hline $\begin{array}{l}\text { Malakopí, North Cappadocian } \\
\text { "farmer" }\end{array}$ & $\begin{array}{l}\text { Turkish } \\
\text { "farmer" }\end{array}$ \\
\hline g. astfis.MASC $<$ & aşçı.Ø \\
\hline $\begin{array}{l}\text { Malakopí, North Cappadocian } \\
\text { "cook" }\end{array}$ & $\begin{array}{l}\text { Turkish } \\
\text { "cook" }\end{array}$ \\
\hline h. $\gamma /$ golt $/$ dzis.MASC & kolcu.Ø \\
\hline Axós Central Cappadocian & Turkish \\
\hline "guard" & "guard" \\
\hline
\end{tabular}

As shown in (14) above, human male loanwords ending in a consonant in Northern Cappadocian are assigned a masculine grammatical gender value and are mainly integrated into the -os subgroup of nouns (examples 14a-d), while human loanwords ending in a vowel or loan agentive nouns in $-\mathrm{cl}^{27}$, mainly into the -is (very few ending in $-a(s)$ e.g. arkadaf "friend" into the -as subgroup) subgroup of nouns (examples 14f-h).

On the contrary, non-animate nouns are integrated into the originally neuter subgroup, the one in $-i$, whether consonant final-which constitutes the vast majority of Turkish loan elements from Turkish - or vowel final and attach to the originally neuter generalized $-j a-j u$ markers (which is usually called in the literature "agglutinative inflection" cf. Dawkins 1916; Janse 2004, forthcoming etc.). It should be noticed that in this case neuter subgrouping marks the characteristic [-human or -animate] and more generally the lack of gender. E.g.:

\footnotetext{
${ }^{26} \varnothing$ marks the lack of grammatical gender.

${ }^{27}$ In Turkish, the suffix $-c I$ is subject to vowel harmony whereby the final vowel can equally appear as $1 / \mathrm{u} /, \mathrm{u} / \mathrm{u} /$ or $\ddot{\mathrm{u}} / \mathrm{y} /$ as well, depending on the preceding vowel.
} 
(15)

\begin{tabular}{|c|c|c|}
\hline t fadir. $N$ & $<$ & cadir. Ø \\
\hline North Cappadocian & & Turkish \\
\hline "tent" & & "tent" \\
\hline diken.NEU & $<$ & diken. $\varnothing$ \\
\hline Delmesó, North Cappadocian & & Turkish \\
\hline thor & & "thorn" \\
\hline varmax.NEU & $<$ & parmak.Ø \\
\hline elmesó, North Cappadocian & & Turkish \\
\hline r" & & "finger" \\
\hline azan.NEU & $<$ & kazan.Ø \\
\hline Axós, Central Cappadocian & & Turkish \\
\hline "copper" & & "copper" \\
\hline irmax(i).NEU & $<$ & irmak.Ø \\
\hline Central Cappadocian & & Turkish \\
\hline "river" & & "river" \\
\hline ara. NEU & $<$ & yara.Ø \\
\hline s, Central Cappadocian & & Turkish \\
\hline 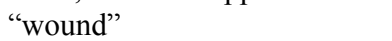 & & "wound" \\
\hline
\end{tabular}

Crucially, the addition of this innovative category in the Cappadocian system-which is absent from Turkish-is not uniform in all Cappadocian subvarieties. Signs of de-systematization appear already in the Central Cappadocian zone. In Axó, human loanword elements marked as masculine on the basis of their animacy (see the examples c., d., e. under 14) co-occur with loanwords, which, although bearing the same semantic characteristic, are marked as neuter. E.g.:

(16)

$\begin{array}{lll}\text { arkadaf.NEU } & < & \text { arkadaş } \\ \text { Axós, Central Cappadocian } & & \text { Turkish } \\ \text { "friend" } & & \text { "friend" } \\ \text { musafir.NEU } & < & \text { misafir } \\ \text { Axós, Central Cappadocian } & & \text { Turkish } \\ \text { "guest" } & & \text { "friend" } \\ \text { bekt fis.NEU } & \text { bekçi } \\ \text { Axós, Central Cappadocian } & & \text { Turkish } \\ \text { "field guard" } & & \text { "field guard" } \\ \text { mifedzis.NEU } & \text { meşeçi } \\ \text { Axós, Central Cappadocian } & & \text { Turkish } \\ \text { "lumberjack" } & & \text { "lumberjack" }\end{array}$

This instability of grammatical gender assignment in loanwords can be seen as a transitory stage (cf. Poplack \& Sankoff, 1984: p. 124) paving the way towards the re-structuring of the specific category as exemplified in South Cappadocian.

In the more "corrupted" (using the words of Dawkins, 1916: p. 112) South Cappadocian zone, this distinction appears to become completely extinct and all nouns, both loan and native elements, either plus or minus human are formally neuter, marking the lack of gender, establishing thus a totally genderless system. E.g.:

(17)

\begin{tabular}{lll} 
tfoban.NEU & $<$ & \multicolumn{1}{c}{ çoban.Ø } \\
Ulağáç, Fertek, South Cappadocian & $\begin{array}{l}\text { Turkish } \\
\text { "shepherd" }\end{array}$ & "shepherd" \\
padifax.NEU & $<$ & padišah.Ø \\
Ulağáç, South Cappadocian & & Turkish \\
"king" & & "king" \\
baldəza.NEU & baldiz.Ø \\
Ulağáç, South Cappadocian & & Turkish \\
"sister-in-law" & & "sister-in-law" \\
bizelik.NEU & $<$ bilezik.Ø \\
Ulağáç, South Cappadocian & & Turkish
\end{tabular}

"bracelet" "bracelet"

What can be seen in Cappadocian is that a totally new categorical distinction emerges, that of animacy, a category that is totally absent both from Greek and Turkish. Assuming thus, that intra-dialectal variation mirrors the gradualness of linguistic change, the addition of this extra category of animacy, present in North and-to some extent-in Central Cappadocian but extinct in the South Cappadocian zone could best, in our view, be accounted for as a temporary resolution, a repair strategy, one of the greater or lesser re-arrangements in the structure of the system in order to pave the way to its reshaping according to the new dynamics and tendencies, due to the prevailing - but not exclusive - influence of the dominant Turkish language; namely towards acquiring a totally genderless status. In this vein, all loanwords are accommodated as neuterswhich marks the lack of gender - and are inflected via the attachment to the generalized-originally most productive neuter-inflectional - ja -ju markers, which, as already mentioned above, is usually called in the literature the "agglutinative inflection". These markers, as already shown in Karatsareas (2011), Melissaropoulou (forthcoming), form part of the one and only inflectional paradigm that tended to generalize and substitute the several original subgroups of nouns (the uniform paradigm can be seen in Table 1).

\section{Discussion}

Although our data involve two totally divergent case studies, on the one hand, contact of a Greek variety with a Indo-European two-gender system of the fusional type, while, on the other hand, contact of a Greek variety with a genderless agglutinative Altaic system, important generalizations focusing both on commonalities and particularities can arise.

Emphasizing commonalities, in both cases what seems to play a very important role in grammatical gender assignment as part of the morphological adaptation process is the semantic feature of animacy. Either in contact between gendered languages or between gendered vs. genderless systems, the most compelling mechanism at work, the one that could be argued to have a universal basis is the correspondence with natural gender, offering further support to the claim that gender has a semantic basis/core (cf. Aksenov, 1984: pp. 17-18). In this sense, one of the most important functions of gender seems to be the grammatical encoding of sex and animacy as a means of nominal classification. Our data are in line with Dahl's (2000a) claims that in situations of language contact animacy as codified in grammatical gender plays a crucial role for the organization of grammar. However, the cut-off point of animacy can be placed in different spots of the animacy hierarchy (cf. Dahl 2000a), i.e. between humans and animals, between higher and lower animals, as is the case in Cappadocian, or between animals and inanimates, varying cross-linguistically.

Table 1.

The emerging inflectional paradigm in Cappadocian.

\begin{tabular}{ccccc}
\hline & Singular & Plural & $\begin{array}{c}\text { Singular atropos } \\
\text { “man” }\end{array}$ & $\begin{array}{c}\text { Plural } \\
\text { atropos “man” }\end{array}$ \\
\hline Nom & $\varnothing$ & $-\mathrm{ja}$ & atropos & atropoz-ja \\
Gen & $-\mathrm{ju}$ & $-(\mathrm{ja}) \mathrm{ju}$ & atropoz-ju & atropoz-(ja)-ju \\
Acc & $\varnothing$ & $-\mathrm{ja}$ & atropos & atropoz-ja \\
\hline
\end{tabular}

Note: adapted from Melissaropoulou forthcoming. 
Apart from the notion of animacy, the other important facet of gender is the formal one, i.e. as an inflectional classifier in the organization of nominal classification types. As illustrated by the data on Grico, apart from the compelling mechanism of animacy, the other important parameter governing grammatical gender assignment in loanwords is the formal (phonologicalstructural) correspondences. This factor seems to be activatedmainly but not exclusively-when structural compatibility among the systems in contact is involved. Both Italian and Grico are gender-inflection class systems, notwithstanding that the grammatical gender values are not identical in both of them. What seems to play a crucial role is that the gender-inflection class classification is present in both systems. In the case of loanword integration into Grico, the notion of gender is strongly related to the notion of inflection class, since assignment of gender entails membership in a specific inflection class (unless a more special rule intervenes and imposes another grammatical gender value).

On the contrary, in Cappadocian where contact between an originally gender-inflection class system and a genderless agglutinative one non displaying inflectional classes is at play, the morphological facet is not realized, only the semantic one, based on animacy which serves - at least at a particular stage - as a classificator of loanwords into the different inflection classes and takes over the formal-morphological function as well. In this case, animacy takes over the classificatory function of integrating human and some higher animals treated as human to the inflection classes that originally contained human nouns, i.e. where marked as masculine or feminine.

Crucially, the progressive loss of the different grammatical gender values and the temporary resolution strategy of the animacy based classification seem to go hand in hand with the progressive loss of the different inflection classes. The direction towards the establishment of a completely genderless system coincides with the direction towards the establishment of a single and uniform inflection class for nouns, remarkably the one coinciding with the most productive neuter inflection class. This choice is not accidental and is accounted for on dual grounds: it was preferred because it is the most productive Christophidou (2003) or in terms of Anastasiadi (1994) the default inflectional class among the neuter classes, marking the lack of gender (in terms of Karatsareas, 2011: p. 8) it assigned inanimate nouns to a semantically appropriate class), and it has probably been triggered as well by the massive influx of consonant-ending Turkish nominal loans into this class, i.e. due to reasons of formal correspondences. Namely, the neuter group of nouns in $-i$ often surfaced as consonant ending due to a general phonological rule operating in Cappadocian, which predicted unstressed high vowel deletion in word final position (often medially as well). For example, the Greek word mati "eye" surfaced as mat. This rule facilitated the massive influx of consonant ending Turkish loanwords in Cappadocian (e.g. razan.NEU < kazan.Ø Turkish "copper") which constitute the vast majority of Turkish nominal loans, since they are formally identical with the corresponding native words, i.e. both end in a consonant. In this case as well, formal correspondences seem to play a role into the morphological integration of loanwords into the recipient system, even though grammatical gender assignment of different grammatical gender values is not involved.

Admittedly, there is no general consensus in the relevant literature on the sources of these innovations, i.e. the loss of grammatical gender distinctions and of the different inflection classes with the development of "agglutinative" inflection in
Cappadocian. Previous research has overwhelmingly accounted for them as instances of contact-induced change, (see, among others, Thomason \& Kaufman, 1988: pp. 215-222; Johanson, 2002: p. 104, Winford, 2005: pp. 402-409, 2010: p. 181) resulting from the influence of Turkish. Karatsareas (2011: pp. 8-9), on the other hand, treated them in strictly language internal terms, i.e. arguing that they result from language internal developments dating back to a linguistic precursor of the Modern Asia Minor and Northern Greek dialects ${ }^{28}$.

With respect to this disagreement what we would claim is that, although we suffer from lack of sources on earlier (Medieval) stages of Cappadocian in order to be in a secure ground when claiming that these innovations are the result of a contact-induced influence or of internal linguistic processes, intense language contact in an environment of regressive bilingualism cannot but have played a crucial role in determining the direction of change, accelerating it or heavily influencing the specific form it has taken. Further support to this claim is offered by the fact that, no matter the similarities (in semantic agreement patterns or in neuter heteroclisis as argued by Karatsareas 2011) none of the other Asia Minor Greek dialects has-tended tobecome a totally genderless system nor was led to the emergence of a unique inflectional paradigm, similar to the so called Cappadocian "agglutinative inflection" 29 .

Loss of grammatical gender and of the different inflection classes were accounted for by Melissaropoulou (forthcoming) as contact-induced simplification phenomena (cf. Nichols, 1992; Trudgill, 2009, 2011) that were adjusted to the system main intra-linguistic characteristics and tendencies aiming to balance out the system. In this spirit, the addition of the extra category of animacy is seen as a temporary repair complexification strategy paving the way towards the simplification of inflectional organization under the influence of Turkish.

Whatever the primary or the secondary cause of change, it seems that the loss of the one category - gender - in Cappadocian entails the loss of the other one as well since the basic function i.e. classification of nouns need not be served anymore, paving the way towards grammar simplification. It is true that complex morphology is not a sufficient condition for the realization of grammatical gender, since there are languages with complex agglutinating morphology and no grammatical gender. Crucially, things seem to go the other way around offering further support to the claim that the distinction of different inflectional classes (or in other words microclasses) entails the realization of different grammatical gender values, while genderless languages generally tend to have no distinction of (macro)classes (see Dressler \& Thorton, 1996: p. 26), leading to a simpler morphology. Further support to this claim is offered by data on Slavonic languages, Germanic languages, and many of the German dialects, Bantu languages or English (cf. Dressler et al., 1996; Corbett, 1991; Hickey, $1999^{30}$ ).

In the case of Grico, on the other hand, the strong correlation

\footnotetext{
${ }^{28}$ Loss of grammatical gender is treated by Karatsareas (2011: pp. 8-9) as a second level development resulting from the extension of the semantic agreement in the neuter form, while loss of inflection classes as a consequence of the emergence of neuter heteroclisis.

${ }^{29}$ Data from language acquisition corroborate the claim that bilingualism can play significant role in the loss of gender, cf. Georgalidou et al. (2005) on the Muslims of the community of Rhodes or Tsimpli (2003) on bilingual speakers in Russian and Turkish.

${ }^{30}$ According to Hickey (1999), present-day Germanic languages and many of the German dialects (such as North Rhenish) have a simpler morphology and, hand-in-hand with this, a simpler gender system.
} 
between gender and inflection class is strongly corroborated in its positive aspect, since it was shown that in loanword integration a specific form (phonological shape) entails assignment of a specific grammatical gender value and membership in a specific inflection class. Crucially, in loanword integration the mismatches between gender assignment and inflection class membership are minimal, establishing a one to one correspondence between a specific gender value and a specific inflection class. Our findings show that in Grico loanwords gender has priority over inflection class, i.e. follows the "normal" direction in terms of Aronoff (1994: p. 74), corroborating the claim that inflection class membership depends on extra-morphological factors such as gender and phonology (cf. Wurzel, 1984; Aronoff, 1994).

Furthermore, our data seem to verify only partially the established claims in the literature that the source language as well may employ special strategies such as the preference for a default gender (see Kilarski, 2003; Stolz, 2009) or for a special gender-noun class. Our data show that in cases of structural compatibility among the involved systems, i.e. the case of Grico, the formal correspondences take priority over a default gender. Crucially, given the sociolinguistic status of the dialect (regressive bilingualism as well), our prediction is that the massive influx of Italo-Romance loanwords may change the morphological shape of the dialect and more specifically the number of inflection classes in use, in the sense that those corresponding to the donors' languages will gain in productivity and consequently will restrict the domain of use of the other existing inflection classes and ultimately may force them into extinction.

In the case of Cappadocian, on the other hand, the situation seems to be more complicated in the sense that Cappadocian adopts the neuter, marking the lack of gender, under the influence of the dominant genderless Turkish language, indicating thus a kind of preference for a default gender value even in its negative realization. On the other hand, the emergence of a unique inflection class, known as agglutinative inflection, is viewed as well as a direct consequence of the loss of grammatical gender under the Turkish influence. However, the preference for the prevalence of this specific neuter class over the other available ones appeals again to reasons of formal correspondences between the original members of this class and the vast majority of Turkish loanwords (after unstressed word final $-i$ deletion both native and loan words end in a consonant, as mentioned above).

Lastly, based on our data we cannot postulate that there are different or additional mechanisms which apply to the assignment of borrowings and not to that of native words. All operative mechanisms (animacy, formal correspondences, analogy) can apply equally efficiently in both native and loanword elements both in cases of structural compatibility and incompatibility among the systems involved (cf. Christophidou, 2003; Ralli, 2005). In other words, recipient systems seem to allude to their available mechanisms, and try to treat and incorporate loanword elements with the same means as native words. These findings offer further support to the status of gender and inflection class as integral parts of the organization of grammar and not just as the burden of diachrony or as what language evolution has not make disappear yet.

\section{Conclusion}

To conclude, hopefully we have shown in the light of the evidence provided by situations of intense language contact with both genetically and typologically divergent systems that gender and inflection class serve as linguistic tools or units to construct representations of the world and fit them into the organization of grammar. Notwithstanding the divergence, our analysis shows that in any case grammatical gender splits into its two major primitives: the semantic one relating to sex and animacy (cf. Animacy Hierarchy, Dahl, 2000a,b), which in turn relates to sociolinguistic and psycholinguistic phenomena, and the structural one, i.e. as an inflectional classifier in the organization of nominal classification types, offering further support to the claim that gender is not a purely morphological or a purely semantic category, but a combination of the two. Each one of the two different facets of the grammatical gender along with the notion of inflection class conjoins the need of the system to provide some type of classification in nouns. However, the realization of those two primitives, of one, or none of them, is subject to parametric variation depending, especially in contact induced systems, on the interplay between the grammatical properties of all the involved systems (e.g. system compatibility vs. incompatibility, simplification phenomena cf. Trudgill, 2009,2011 ). Thus, our conception of gender and inflection class is in a similar line with Aikhenvald (2000: p. 307) claiming that '[classification systems] can offer a 'unique window' into studying how humans construct representations of the world and encode them into languages". In case of language contact in particular, the dynamics of change in classification of nouns, and more specifically in the realization of gender and inflection class as well as in their interplay are revealed, allowing for further predictions on what features have a universal basis, and more generally on the direction of change.

\section{REFERENCES}

Aikhenvald, A. Y. (2000). Classifiers: A typology of noun categorization devices. Oxford: Oxford University Press.

Aksenov, A. T. (1984). On the problem of the extralinguistic motivation of grammatical gender. Voprosy jazykoznanija, 1, 14-25.

Anastasiadi-Symeonidi, A. (1994). Neological borrowing in Modern Greek. Thessaloniki.

Aronoff, M. (1994). Morphology by itself: Stems and inflectional classes. Cambridge, MA/London: MIT Press.

Bakker, P. (1997). Athematic morphology in Romani: The borrowing of a borrowing pattern. In Y. Matras, P. Bakker, \& H. Kyuchukov (Eds.), The typology and dialectology of Romani (pp. 1-21). Amsterdam: John Benjamins.

Bakker, P., \& Mous. M. (1994). Mixed languages: 15 case studies in language intertwining (Studies in language and language use 13). Amsterdam: Institute for Functional Research into Language and Language Use (IFOTT).

Bichakjian, B. H. (1999). Language evolution and the complexity criterion. Psycoloquy, 10, 33.

Bloomfield, L. (1933). Language. New York: Holt, Rinehart \& Winston.

Braunmüller, K. (2000). Gender in North Germanic: A diasystematic and functional approach. In B. Unterbeck, \& M. Rissanen (Eds.), Gender in grammar and cognition, Vol. 1. Approaches to gender, Vol. 2. Manifestations of gender (pp. 25-53). Berlin: Mouton de Gruyter.

Bybee, J. (1985). Morphology: A study of the relation between meaning and form. Amsterdam: John Benjamins.

Caratzas, S. C. (1958). The origin of Modern Greek dialects of Southern Italy. Paris: Les Belles Lettres

Carstairs, A. (1987). Allomorphy in inflection. London: Croom Helm.

Carstairs-McCarthy, A. (1994). Inflection classes, gender, and the principle of contrast. Language, 70, 737-787.

http://dx.doi.org/10.2307/416326 


\section{MELISSAROPOULOU}

Carstensen, B. (1980). The gender of English loan-words in German. Studia Anglica Posnaniensia, 12, 3-25.

Christophidou, A. (2003). Gender and inflection in Greek (a natural approach). In A. Anastasiadis-Symeonidis, A. Ralli, \& D. Cheila Markopoulou (Eds.), Gender (pp. 100-131). Athens: Patakis.

Corbett, G. (1991). Gender. Cambridge: Cambridge University Press. http://dx.doi.org/10.1017/CBO9781139166119

Corbett, G. (2005). The number of genders. In M. Haspelmath, M. S. Dryer, D. Gil, \& B. Comrie (Eds.), The world Atlas of language structures (pp. 126-129). Oxford: Oxford University Press.

Corbett, G. (2007). Gender and noun classes. In T. Shopen (Ed.), Language typology and syntactic description: III: Grammatical categories and the lexicon (pp. 241-279). Cambridge: Cambridge University Press.

Corbett, G. (2008). Canonical inflectional classes. In F. Montermini, G. Boyé, \& J. Tseng (Eds.), Selected Proceedings of the 6th Décembrettes: Morphology in Bordeaux (pp. 1-11). Somerville, MA: Cascadilla Proceedings Project.

Corbett, G., \& Fraser, N. (2000). Default genders. In B. Unterbeck, M. Rissanen, T. Nevalainen, \& M. Saari (Eds.), Gender in grammar and cognition (Trends in Linguistics: Studies and Monographs 124) (pp. 55-97). Berlin: Mouton de Gruyter.

Cornips, L. (2008). Loosing grammatical gender in Dutch. The result of bilingual acquisition and/or an act of identity? International Journal of Bilingualism, 12, 105-124.

Dahl, Ö. (2000a). Animacy and the notion of semantic gender. In B. Unterbeck, M. Rissanen, T. Nevalainen, \& M. Saari (Eds.), Gender in grammar and cognition, I: Approaches to gender (pp. 99-115). Berlin: Mouton de Gruyter.

Dahl, Ö. (2000b). Elementary gender distinctions. In B. Unterbeck, M. Rissanen, T. Nevalainen, \& M. Saari (Eds.), Gender in grammar and cognition, II: Manifestations of gender (pp. 577-593). Berlin: Mouton de Gruyter.

Dahl, Ö. $(2000 \mathrm{c})$. The growth and maintenance of linguistic complexity. Amsterdam/Philadelphia: John Benjamins Publishing Company.

Dawkins, R. M. (1916). Modern Greek in Asia Minor: a study of the dialects of Silli, Cappadocia and Phárasa with grammar, texts, translations and glossary. Cambridge: Cambridge University Press.

Dressler, W. (1987). Word formation (WF) as part of natural morphology. In Dressler, W., W. Mayerthaler, O. Panagl, \& W. Wurzel (Eds.), Leitmotifs in natural morphology (pp. 99-126). Amsterdam: Benjamins.

Dressler, W. U., \& Thornton. A. M. (1996). Italian nominal inflection. Wiener Linguistische Gazette, 57-59, 1-26.

Dressler, R., Drazyk, D., Dziubalska K., \& Jagla. E. (1996). On the earliest stages of acquisition of Polish declension. Wiener Linguistische Gazette, 53-54, 1-21.

Filieri, V. G. (2001). I speak Grico. A basic method on Greek of Salento in comparison with Standard Modern Greek. Greece: University of Ioannina, Center of Greek Language and Culture.

Fanciullo, F. (2001). On the origins of Modern Greek in Southern Italy. In M. Janse, B. Joseph, \& A. Ralli (Eds.), Proceedings of the 2nd International Conference on Modern Greek Dialects and Linguistic Theory (pp. 67-77). Patras: Unversity of Patras.

Georgalidou, M., Spyropoulos V., Kaili, H., \& Revithiadou. A. (2005). Linguistic and sociolinguistic aspects of a Rhodian Greek variety. The 6th International Linguistics Conference of the Organisation for the Propagation of the Greek Language "The Dialectal Varieties of Greek from the Ancient Era until Today". Coriliano Otranto, 6-8 October 2005.

Haspelmath, M. (2008). Loanword typology: Steps toward a systematic cross-linguistic study of lexical borrowability. In T. Stolz, D. Bakker, $\&$ R. Salas Palomo (Eds.), Aspects of language contact: New theoretical, methodological and empirical findings with special focus on Romancisation processes (pp. 43-62). Berlin/New York: Mouton de Gruyter,

Haspelmath, M., \& Tadmor, U. (2009). Loanwords in the world's languages: A comparative handbook. Berlin: Mouton de Gruyter.

Haugen, E. (1950). The analysis of linguistic borrowing. Language, 26, 210-331. http://dx.doi.org/10.2307/410058
Haugen, E. (1953). The Norwegian language in America: A study in bilingual behavior. Vol. 1: The bilingual community; Vol. II. The American dialects of Norwegian. Bloomington: Indiana University Press.

Hickey, R. (1999). On the phonology of gender in Modern German. In: M. Rissanen, \& B. Unterbeck (Eds.), Gender in grammar and cognition (pp. 621-663). Berlin: Mouton-de Gruyter.

Ibrahim, M. H. (1973). Grammatical gender: Its origin and development. The Hague: Mouton.

Janse, M. (2004). Animacy, definiteness and case in Cappadocian and other Asia Minor Greek dialects. Journal of Greek Linguistics, 5, 3-26. http://dx.doi.org/10.1075/jgl.5.03jan

Janse, M. (2009). Greek-Turkish language contact in Asia Minor Études Helléniques/Hellenic Studies, 17, 37-54.

Janse, M. (forthcoming). Cappadocian. In Tzitzilis (Ed.), The Greek language and its dialects. Thessaloniki: Center for Modern Greek Studies, Manolis Triantafyllides Foundation.

Johanson, L. (1992). Structural factors in Turkish language contacts. Stuttgart: Franz Steiner.

Johanson, L. (2002). Contact-induced linguistic change in a codecopying framework. In M. C. Jones, \& E. Esch (Eds.), Language change: The interplay of internal, external and extra-linguistic factors (Contributions to the sociology of language, 86) (pp. 285-313). Berlin: Mouton de Gruyter.

Karanastasis, A. (1984). Historical lexicon of the Greek dialects of Southern Italy Vol. 1. Athens: Academy of Athens.

Karanastasis, A. (1997). Grammar of the Greek dialects of Southern Italy. Athens: Academy of Athens.

Katsoyannou, M. (1996). Greek in Southern Italy: Morphology of nouns and evolution of the nominal system. Studies in Greek Linguistics, 17, 328-341.

Katsoyannou, M. (1999). Greek in Southern Italy: The sociolinguistic perspective. In A. Mozer (Eds.), Greek Linguistics 97' Proceedings of the 3rd International Conference on Greek Language (pp. 605613). Athens: Greek Letters.

Karatsareas, P. (2011). A study of Cappadocian Greek Nominal morphology from a diachronic and dialectological perspective. Ph.D. Dissertation, Cambridge: University of Cambridge.

Kilarski, M. (2003). Gender assignment in Danish, Swedish and Norwegian: A comparison of the status of assignment criteria. Nordlyd, 31.2, 261-274.

Lyons, J. (1977). Semantics. 2 Vols. Cambridge: Cambridge University Press.

Maiden, M., \& Parry, M. (1997). The dialects of Italy. London: Routledge.

Mavrochalyvidis, G., \& Kesisoglou. I. I. (1960). The dialect of Axos. Athens: Institut Français d'Athènes.

Mavrochalyvidis, G. (1990). Cappadocian Axo. Vol. 2. Athens: Center for Modern Greek Studies.

Manolessou, I. (2005). The Greek dialects of Southern Italy: An overview. Cambridge Papers in Modern Greek, 13, 103-125.

McWhorter, J. H. (2001). The world's simplest grammars are creole grammars. Linguistic Typology, 5, 125-166. http://dx.doi.org/10.1515/lity.2001.001

Melissaropoulou, D. (forthcoming). On the role of language contact in the reorganization of grammar: A case study on two Modern Greek contact induced dialects. In Proceedings of the 5th International Conference of Modern Greek Dialects and Linguistic Theory. Ghent, 20-22 September 2012

Minas, K. (1994). The language of published medieval manuscripts of South Italy and Sicily. Athens: Academy of Athens.

Minas, K. (2004). Studies in Modern Greek dialectology. Athens: Typothito.

Mufwene, S. S. (2001). The ecology of language evolution. Cambridge: Cambridge University Press. http://dx.doi.org/10.1017/CBO9780511612862

Newton, B. (1963). The grammatical integration of Italian and Turkish substantives into Modern Greek. Word, 19, 20-30.

Nichols, J. (1992). Linguistic diversity in space and time. Chicago: Chicago University Press. 


\section{MELISSAROPOULOU}

http://dx.doi.org/10.7208/chicago/9780226580593.001.0001

Poplack, S., \& Sankoff. D. (1984). Borrowing: The synchrony of integration. Linguistics, 22, 99-135. http://dx.doi.org/10.1515/ling.1984.22.1.99

Poplack, S., Pousada, A., \& Sankoff. D. (1982). Competing influences on gender assignment: Variable process, stable outcome. Lingua, 57, 1-28. http://dx.doi.org/10.1016/0024-3841(82)90068-7

Profili, O. (1985). Romanisation of a form of Greek spoken in Southern Italy by the neighbouring speakers of Romance varieties. In Proceeding of the 17th International Conference of Romance Linguistics and Philology (pp. 129-139). Aix-en-Provence: Université de Provence.

Profili, O. (1999a). Greek in Southern Italy. In A.-Ph. Christidis (Ed.), Dialectal enclaves of the Greek Language (pp. 31-37). Athens: YPEPTH - Centre for Greek Language.

Profili, O. (1999b). Revitalization of Grico in "Grecia Salentina". In A.-Ph. Christidis (Ed.), Dialectal enclaves of the Greek Language (pp. 47-54). Athens: YPEPTH-Centre for Greek Language.

Ralli, A. (2000). A feature-based analysis of Greek nominal inflection. $\Gamma \lambda \omega \sigma \sigma o \lambda o \gamma i \alpha /$ Glossologia, 11-12, 201-227.

Ralli, A. (2002). The role of morphology in gender determination: Evidence from Modern Greek. Linguistics, 40, 519-551. http://dx.doi.org/10.1515/ling.2002.022

Ralli, A. (2003). Grammatical gender determination in Modern Greek nouns. In A. Anastassiadis-Symeonidis, A. Ralli, \& D. Chila-Markopoulou (Eds.), Gender (pp. 57-99). Athens: Patakis.

Ralli, A. (2005). Morphology. Athens: Patakis.

Ralli, A. (2006). On the role of allomorphy in inflectional morphology: Evidence from dialectal variation. In G. Sica (Ed.), Open problems in linguistics and lexicography (pp. 101-120). Milano: Polimetrica.

Rolhfs, G. (1977). Historical grammar of Italian-Greek dialects. Munchen: C.H. Beck'sche Verlagsbuchhandlung.

Sankoff. G. (2001). Linguistic outcomes of language contact. In P. Trudgill, J. Chambers, \& N. Schilling-Estes (Eds.), Handbook of sociolinguistics (pp. 638-668). Oxford: Basil Blackwell.

Sasse, H. J. (1992). Language decay and contact-induced change: Similarities and differences. In M. Brenzinger (Ed.), Language death (pp. 59-80). Berlin/New York: Mouton de Gruyter.

Spencer, A. (1999). Gender as an inflectional category. Essex Research Reports in Linguistics, 25, 35-72.

Stomeo, P. (1996). Unpublished stories of Sternatia Grico. Lecce:
Edizioni "La nuova Ellade".

Stolz, C. (2009). Loan word gender in Maltese, with a special focus on gender copy. In B. Comrie, R. Fabri, E. Hume, M. Mifsud, T. Stolz, \& M. Vanhove (Eds.), Introducing Maltese linguistics. Proceedings of the first international conference on Maltese linguistics (pp. 321353). Amsterdam/Philadelphia: John Benjamins.

Thomason, S. G., \& Kaufman. T. (1988). Language contact, creolization and genetic linguistics. Berkeley: University of California Press.

Tommasi, S. (1996). World was destroyed. Ghetonia: Kalimera

Thornton, A. (2001). Some reflections on gender and inflectional class assignment in Italian. In C. Schaner-Wolles, J. Rennison, \& F. Neubarth (Eds.), Naturally! Linguistic studies in honour of Wolfgang Ulrich Dressler presented on the occasion of his 60th Birthday. Torino: Rosenberg \& Sellier.

Trudgill, P. (1999). Language contact and the function of linguistic gender. Poznań Studies in Contemporary Linguistics, 35, 133-152.

Trudgill, P. (2009). Sociolinguistic typology and complexification. In S. Geoffrey, D. Gil, \& P. Trudgill (Eds.), Language complexity as an evolving variable (pp. 98-109). Oxford: Oxford University.

Trudgill, P. (2011). Sociolinguistic Typology: Social Determinants of Linguistic Complexity (Oxford Linguistics). Oxford: Oxford University Press.

Tsimpli, I. (2003). Acquisition of gender in Greek as a second language. In A. Anastasiadis-Symeonidis, A. Ralli, \& D. Cheila Markopoulou (Eds.), Gender (pp. 168-189). Athens: Patakis.

Van Coetsem, F. (1988). Loan phonology and the two transfer types in language contact. Dordrecht: Foris.

Weinreich, U. (1968). Languages in contact: Findings and problems. The Hague: Mouton.

Winford, D. (2005). Contact-induced changes: Classification and processes. Diachronica, 22, 373-427. http://dx.doi.org/10.1075/dia.22.2.05win

Winford, D. (2010). Contact and borrowing. In R. Hickey (Ed.), The handbook of language contact (pp. 170-187). Malden, MA/Oxford: Wiley-Blackwell. http://dx.doi.org/10.1002/9781444318159.ch8

Wurm, S., Mühlhäusler, P., \& Tryon. D. T. (1996). Atlas of languages of intercultural communication in the Pacific, Asia, and the Americas. Berlin: Mouton de Gruyter. http://dx.doi.org/10.1515/9783110819724

Wurzel, W. (1984). Inflectional morphology and naturalness. Berlin: Akademie-Verlang.

\section{Appendix}

\section{Subgroupings of Cappadocian}

\section{North Cappadocian}

- Northwest Cappadocian

- Sílata

- Anakú

- Floyitá

- Malakopí

- Northeast Cappadocian

- Sinasós

- Potámya

- Delmesó

Central Cappadocian

- Axó

- Mistí

South Cappadocian

- Southwest Cappadocian

- Araván, Gúrzono

- Ferték
- Southeast Cappadocian

- Ulağáç

- Semenderé 